\title{
Nitrifying granules cultivation in a sequencing batch reactor at a low organics-to-total nitrogen ratio in wastewater
}

\author{
A. Cydzik-Kwiatkowska $\cdot$ I. Wojnowska-Baryła
}

Received: 30 September 2010 / Accepted: 28 March 2011 /Published online: 27 May 2011

(C) The Author(s) 2011. This article is published with open access at Springerlink.com

\begin{abstract}
It is possible to cultivate aerobic granular sludge at a low organic loading rate and organics-tototal nitrogen $(\mathrm{COD} / \mathrm{N})$ ratio in wastewater in the reactor with typical geometry (height/diameter=2.1, superficial air velocity $=6 \mathrm{~mm} / \mathrm{s}$ ). The noted nitrification efficiency was very high $(99 \%)$. At the highest applied ammonia load $\left(0.3 \pm 0.002 \mathrm{mg} \mathrm{NH}_{4}{ }^{+}-\mathrm{N}\right.$ g total suspended solids $\left.(\mathrm{TSS})^{-1} \mathrm{day}^{-1}, \mathrm{COD} / \mathrm{N}=1\right)$, the dominating oxidized form of nitrogen was nitrite. Despite a constant aeration in the reactor, denitrification occurred in the structure of granules. Applied molecular techniques allowed the changes in the ammonia-oxidizing bacteria (AOB) community in granular sludge to be tracked. The major factor influencing AOB number and species composition was ammonia load. At the ammonia load of $0.3 \pm 0.002 \mathrm{mg} \mathrm{NH}_{4}{ }^{+}-\mathrm{N} \mathrm{g} \mathrm{TSS}^{-1}$ day $^{-1}$, a highly diverse $\mathrm{AOB}$ community covering bacteria belonging to both the Nitrosospira and Nitrosomonas genera accounted for ca. $40 \%$ of the total bacteria in the biomass.
\end{abstract}

\begin{tabular}{|c|c|}
\hline \multicolumn{2}{|c|}{ Abbreviations } \\
\hline $\mathrm{AOB}$ & Ammonia-oxidizing bacteria \\
\hline $\mathrm{COD} / \mathrm{N}$ & Organics-to-total nitrogen ratio \\
\hline DO & Dissolved oxygen \\
\hline FA & Free ammonia \\
\hline$h / d$ & Reactor height/diameter ratio \\
\hline OLR & Organic loading rate \\
\hline PCR-DGGE & $\begin{array}{l}\text { Polymerase chain reaction-denaturing } \\
\text { gradient gel electrophoresis }\end{array}$ \\
\hline SBR & Sequencing batch reactor \\
\hline
\end{tabular}

A. Cydzik-Kwiatkowska $(\bowtie) \cdot I$. Wojnowska-Baryła

Department of Environmental Biotechnology,

University of Warmia and Mazury in Olsztyn,

Słoneczna 45G,

10-709 Olsztyn, Poland

e-mail: agnieszka.cydzik@uwm.edu.pl

$\begin{array}{ll}\text { SRT } & \begin{array}{l}\text { Sludge retention time } \\ \mathrm{SVI}_{5}\end{array} \\ & \begin{array}{l}\text { Sludge volume index after } 5 \mathrm{~min} \\ \text { of sedimentation }\end{array} \\ \text { TSS } & \begin{array}{l}\text { Total suspended solids } \\ \text { Volatile suspended solids }\end{array}\end{array}$

\section{Introduction}

In technological practice, removal of nitrogen is most often accomplished using autotrophic nitrification followed by heterotrophic denitrification. For the removal of nitrogen, reactors containing activated sludge, biofilm, or granular sludge are employed. The latter type of biomass structure possesses many desirable properties such as short sedimentation time, high microorganism concentration, good solidliquid separation, and resistance to high concentrations of organic and toxic compounds (Liu and Tay 2004). From an engineering perspective, the installations employing technologies based on aerobic granular sludge require a smaller surface area and clarifier dimensions, shorter standstill for settling, and a longer time for the biological removal of pollutants. The self-immobilization that takes place during granule formation prevents slowly growing bacteria, e.g., nitrifiers, from being washed out from the system.

Supernatants from sludge digesters, landfill leachate, and industrial wastewater treated by anaerobic fermentation are characterized by a high ammonia concentration and a low organics-to-total nitrogen ratio $(\mathrm{COD} / \mathrm{N})$. These wastewater types are most often treated together with municipal wastewater introduced to the main stream of a technological system that degrades the $\mathrm{C} / \mathrm{N}$ ratio in the influent, thus negatively affecting the removal of nitrogen (Head and 
Oleszkiewicz 2000). It would be of considerable advantage to find a technological solution which allows for the efficient oxidation of nitrogen compounds in such a wastewater in a side stream of the plant.

The use of molecular techniques allows an insight to be gained into changes in microbial consortia involved in the removal of pollutants from wastewater in relation to environmental conditions (Gilbride et al. 2006). Proper choice of primers and probes enables specific groups of microorganisms in biomass to be characterized. Data obtained using molecular tools allow shifts in species structure or number of bacteria to be observed and correlate these with the technological parameters of the process. The effective processing of wastewater characterized by the high ammonia concentration depends on the key organisms for nitrification that are ammonia-oxidizing bacteria (AOB). Understanding the ecology of AOB can improve the treatment performance and control mechanisms. Therefore, the variation in the AOB community in aerobic granules during the experiment was monitored using polymerase chain reaction-denaturing gradient gel electrophoresis (PCR-DGGE), molecular cloning, and real-time PCR.

Aerobic granular sludge technology is at the moment mainly investigated in laboratory conditions, and only a few full-scale reactors operate in the world. In order to enable swift transition from laboratory to full-scale systems for the removal of nitrogen, it is necessary to understand the fundamentals of nitrogen conversions and microbial population dynamics in aerobic granules. Since most of the experiments with granular sludge are carried out in column reactors with reactor height/diameter ratio $(h / d) \geq 10$ (Beun et al. 1999; Toh et al. 2003), it is also important to assess the possibilities of adaptation of already existing reactors with typical geometry for this process.

In the present research, the nitrogen and carbon conversions and changes in the AOB community were investigated in granular biomass cultivated in a sequencing batch reactor (SBR) with $h / d$ of 2.1 at a low $\mathrm{COD} / \mathrm{N}$ ratio in the influent.

\section{Materials and methods}

SBR operation The experiment was carried out for 85 days in an SBR with a working volume of $5.0 \mathrm{~L}$ and $h / d$ of 2.1. As a seed biomass, granular sludge adapted to removal of organic carbon was used (Cydzik-Kwiatkowska et al. 2009a). The temperature in the experimental room was ambient $\left(18-21^{\circ} \mathrm{C}\right)$, and the $\mathrm{pH}$ of the reactor was kept between 7 and 8 . The reactor was aerated at a rate of $8 \mathrm{~L} / \mathrm{min}$, resulting in a superficial upflow air velocity of $6 \mathrm{~mm} / \mathrm{s}$. The SBR operated in a 12-h cycle, with the following operating strategy: filling ( $5 \mathrm{~min})$, aeration
(705 $\mathrm{min})$, settling (5 $\mathrm{min})$, decantation (5 $\mathrm{min})$. The synthetic wastewater was prepared according to Coelho et al. (2000; modified). As an organic carbon source, sodium acetate was added to the wastewater to a final concentration of about $300 \pm 60 \mathrm{mg} \mathrm{COD} / \mathrm{L}$ that resulted in an organic loading rate (OLR) of $0.45 \mathrm{~kg} \mathrm{COD} \mathrm{m}^{-3}$ day $^{-1}$. A wastewater exchange ratio of $75 \%$ was employed.

In the first cycle of the experiment, $50 \mathrm{~mL}$ of AMNITE NS500 (Wirexim Biotechnologie, Poland), heterologous mixture of AOB with Nitrosomonas europaea as a dominant species, was added to the reactor. During the first 95 cycles, $\mathrm{NH}_{4}{ }^{+}-\mathrm{N}$ concentration in the influent was maintained at the level of $162 \pm 12 \mathrm{mg} / \mathrm{L}$ that resulted in a $\mathrm{COD} / \mathrm{N}$ ratio of $\approx 2$. After reaching stable nitrification detected as a constant $( \pm 5 \%)$ effluent substrate concentration (Jin et al. 2008) in cycle 96, ammonia concentration in the influent was doubled and kept at the level of $292 \pm$ $12 \mathrm{mg} / \mathrm{L}$ (influent $\mathrm{COD} / \mathrm{N}=1$ ). In order to keep the alkalinity, the theoretical $\mathrm{NaHCO}_{3}$ requirement for nitrification was added to wastewater. Total suspended solids (TSS) concentration averaged $1.6 \pm 0.12 \mathrm{~g}$ TSS/L, volatile suspended solids $(\mathrm{VSS})=0.53 \mathrm{TSS}$. Sludge volume index was measured after $5 \mathrm{~min}$ of sedimentation $\left(\mathrm{SVI}_{5}\right)$. Analytical measurements were performed according to APHA (1992). Sludge retention time (SRT) and biomass production, expressed as the observed coefficient of biomass production $\left(Y_{\mathrm{obs}}\right)$, were calculated according to Klimiuk and Kulikowska (2006).

In order to determine kinetic parameters, in the 162th and 168 th cycles, wastewater samples were taken every $1-3 \mathrm{~h}$ during the SBR cycle to follow the COD and nitrogen compound concentration changes in the reactor. The average values from the two cycles were used for calculations. All constants of reaction rates were determined based on the experimental data by non-linear regression with the use of Statistica 7 (StatSoft, USA). The $r$ values were divided by VSS and expressed per unit of biomass. Granulation was documented using a digital camera (Canon G5; resolution, $5 \mathrm{Mpx}$ ). The average diameter of the granules was measured in the photographs as a circle-equivalent diameter of 100 granules randomly obtained from the reactor in the 140th cycle.

$P C R-D G G E$ DNA was extracted in duplicate from approximately $400 \mathrm{mg}$ of centrifuged sludge sample using a FastDNA ${ }^{\circledR}$ SPIN ${ }^{\circledR}$ Kit (Q-BIOgene, Canada). PCRs were performed in an Eppendorf ${ }^{\circledR}$ Mastercycler Gradient (Eppendorf, Germany). Primer sequences and annealing temperatures are shown in Table 1. For amoA, amplification nested PCR was applied. The primary PCR mixture contained $1.7 \mathrm{ng} / \mu \mathrm{L}$ of extracted DNA, $0.5 \mu \mathrm{mol} / \mathrm{L}$ of primers $301 \mathrm{~F} / 302 \mathrm{R}, 100 \mu \mathrm{mol} / \mathrm{L}$ of deoxynucleoside triphosphate mixture (Promega, USA), $1.5 \mathrm{U}$ of GoTaq ${ }^{\circledR}$ 
Table 1 PCR primers used

\begin{tabular}{|c|c|c|c|c|c|}
\hline Technique & Primer & $\begin{array}{l}\text { Nucleotide } \\
\text { sequence } 5^{\prime} \rightarrow 3^{\prime}\end{array}$ & $\begin{array}{l}\text { Annealing } \\
\text { temperature } \\
\left({ }^{\circ} \mathrm{C}\right)\end{array}$ & $\begin{array}{l}\text { Amplicon/PCR } \\
\text { product length (bp) }\end{array}$ & Reference \\
\hline \multirow[t]{2}{*}{ PCR-DGGE } & $\begin{array}{l}301 \mathrm{~F} \\
302 \mathrm{R}\end{array}$ & $\begin{array}{l}\text { gactgggacttctggetggactggaa } \\
\text { tttgatcccetctggaaagcettcttc }\end{array}$ & 52 & amoA $(\approx 670)$ & Norton et al. (2002) \\
\hline & $\begin{array}{l}\operatorname{amoA}-2 R \\
\operatorname{amoA}-1 \mathrm{~F}\end{array}$ & $\begin{array}{l}\text { cccctctgcaaagcettcttc } \\
\text { tttctactggtggt }^{\mathrm{a}}\end{array}$ & 62 & aтоA $(\approx 490)$ & $\begin{array}{l}\text { Rotthauwe et al. (1997) } \\
\text { (modified by Nicolaisen } \\
\text { and Ramsing 2002) }\end{array}$ \\
\hline \multirow[t]{2}{*}{ Real-time PCR } & $\begin{array}{l}\text { amoA1F } \\
\text { amoA2R }\end{array}$ & $\begin{array}{l}\text { ggggtttctactggtggt } \\
\text { cccctc(gt)g(cg)aaagccttcttc }\end{array}$ & 60 & amoA $(\approx 490)$ & Rotthauwe et al. (1997) \\
\hline & $\begin{array}{l}519 \mathrm{f} \\
907 \mathrm{r}\end{array}$ & $\begin{array}{l}\text { cagcmgccgcggtaanwc } \\
\text { ccgtcaattcmtttragtt }\end{array}$ & 50 & 16S rDNA $(\approx 407)$ & Lane (1991) \\
\hline
\end{tabular}

${ }^{\mathrm{a}}$ cgc $\operatorname{cgc}$ gcg gcg ggc ggg geg ggg gcg ggg

DNA Polymerase (Promega), $6 \mu \mathrm{L}$ of $10 \times$ reaction buffer supplied with polymerase, $1.5 \mathrm{mmol} / \mathrm{L} \mathrm{MgCl}_{2}$, and sterile water to a final volume of $30 \mu \mathrm{L}$. In the second PCR, the same mixture was applied except for $0.2 \mu \mathrm{L}$ of PCR product from the primary amplification as a template and primers amoA-1F/amoA-2R. The PCR amplifications were carried out using the following program: $95^{\circ} \mathrm{C}$ for $5 \mathrm{~min}, 35$ cycles (primary amplification) or 25 (secondary amplification) of denaturation at $94^{\circ} \mathrm{C}$ for $30 \mathrm{~s}$, annealing for $45 \mathrm{~s}$, extension at $72^{\circ} \mathrm{C}$ for $1 \mathrm{~min}$, and a final elongation at $72^{\circ} \mathrm{C}$ for $5 \mathrm{~min}$. The presence of PCR products was confirmed by analyzing $5 \mu \mathrm{L}$ of the product on a $0.8 \%$ agarose gel stained with ethidium bromide.

The DGGE procedure was performed according to Cydzik-Kwiatkowska et al. (2009b). Representatives of amo $A$ gene amplicons that were clear and had a high intensity were excised from the DGGE gel, re-amplified, and sequenced in the Institute of Biochemistry and Biophysics, Polish Academy of Science (www.oligo.ibb. waw.pl). The determined nucleotide sequences were compared with sequences in the GenBank using the BLASTn program (Altschul et al. 1997), deposited in the GenBank under accession no. HQ315545-HQ315552 and aligned using Clustal W (http://www.ebi.ac.uk/Tools/ clustalw2/index.html). On the basis of the alignment, the tree of the percentage sequence similarity with the sequences of AOB retrieved with the BLASTn tool in the NCBI database was constructed using the JalView program (Waterhouse et al. 2009).

Real-time PCR Quantification of the amoA gene was performed in a reaction mixture that contained template DNA $(1 \mathrm{ng} / \mu \mathrm{L}), 12.5 \mu \mathrm{L}$ of Power SYBR ${ }^{\circledR}$ Green PCR Master Mix (Applied Biosystems, USA), $50 \mathrm{nmol} / \mathrm{L}$ of each primer (Table 1), $25 \mathrm{nmol} / \mathrm{L}$ of $\mathrm{KCl}$, and water to a final volume of $25 \mu \mathrm{L}$. The protocol for amoA quantification was as follows: $2 \mathrm{~min}$ at $50^{\circ} \mathrm{C}, 10 \mathrm{~min}$ at $95^{\circ} \mathrm{C}$, and 40 cycles consisting of $30 \mathrm{~s}$ at $95^{\circ} \mathrm{C}$ and $1 \mathrm{~min}$ at $60^{\circ} \mathrm{C}$. The reaction mixture for $16 \mathrm{~S}$ rDNA amplification was as for amoA gene analysis; however, primer (519f/907r) concentration was $100 \mathrm{nmol} / \mathrm{L}$, and no $\mathrm{KCl}$ was added. The protocol for bacterial $16 \mathrm{~S}$ rDNA quantification was as follows: $2 \mathrm{~min}$ at $50^{\circ} \mathrm{C}, 10 \mathrm{~min}$ at $95^{\circ} \mathrm{C}$, and 40 cycles consisting of $15 \mathrm{~s}$ at $95^{\circ} \mathrm{C}, 1 \mathrm{~min}$ at $50^{\circ} \mathrm{C}$, and $1 \mathrm{~min}$ at $60^{\circ} \mathrm{C}$. Each sample was amplified in triplicate in the presence of negative and positive controls. The amplification was followed by a denaturation step to confirm the melting temperature of the PCR products; the products were also electrophoresed in the presence of a molecular marker. Reactions were carried out in a 7500 Real-Time PCR System using MicroAmp optical tubes and caps (Applied Biosystems). The fluorescence signal was normalized by dividing the SYBR dye emission by the reference dye (ROX) signal intensity. The threshold was defined as $10 \times$ standard deviation of the average intensity of background fluorescence in negative controls. Data were analyzed with a Sequence Detection Software, ver. 1.3 (Applied Biosystems). For calculations, it was assumed that the average number of 16S rDNA gene copies in a bacterial genome is 7 and that the average number of amoA gene copies in an AOB genome is 2.5 (Okano et al. 2004). Results were expressed as the number of bacteria cells per reaction tube (Suzuki et al. 2000).

Standard curves for amoA and bacterial $16 S$ rDNA quantification Standard curves for amoA and bacterial $16 \mathrm{~S}$ rDNA quantification was generated with serial dilutions of a linearized plasmid with an inserted amoA gene. Bacterial $16 \mathrm{~S}$ rDNA was calibrated with genomic DNA extracted from Escherichia coli JM109 (Promega). Slopes of standard curves for $C_{\mathrm{T}}$ plotted against the logarithm of the number of gene copies and the corresponding determination coefficients were $-3.9\left(R^{2}=0.996\right)$ and $-3.48\left(R^{2}=0.966\right)$ for $a m o A$ and $16 \mathrm{~S}$ rDNA quantification, respectively. 


\section{Results and discussion}

In the experiment, as seed sludge, aerobic granules cultivated on organic carbon were used since this procedure provides a shortened start-up period. After the first 20 cycles of the experiment, $\mathrm{SVI}_{5}$ did not cross the value of $50 \mathrm{~mL} / \mathrm{g}$ typical for granular sludge (Toh et al. 2003). The average diameter of granules measured at the 140th cycle was $1.9 \pm 1.7 \mathrm{~mm}$. Granules had a compact and roundshaped structure with a clear outer shape (Fig. 1). Biomass concentration in the reactor during the experiment, independently on the COD/N ratio in wastewater, was at the level of $1.6 \pm 0.12 \mathrm{~g}$ TSS/L. SRT was high and equaled $56 \mathrm{~d}$; the TSS concentration in the effluent was very low and averaged $0.017 \pm 3.5 \mathrm{mg} \mathrm{TSS} / \mathrm{L}$.

The reactor geometry is of importance with regard to granular sludge formation since the high $h / d$ ratio of the reactor ensures a longer trajectory of circular flow favoring aggregates shearing (Liu and Tay 2004). The shear force resulting from hydrodynamic turbulence caused by an upflow aeration increases specific oxygen utilization rate, the hydrophobicity of cells and stimulates the production of polysaccharides that stabilize the granule structure (Tay et al. 2001). Beun et al. (1999) have demonstrated that smooth granules are formed at a superficial gas velocity of $41 \mathrm{~mm} / \mathrm{s}$ while other investigated velocities (14 and $20 \mathrm{~mm} / \mathrm{s}$ ) do not allow for stable granule formation. Tay et al. (2001) have reported that granules are not formed in the reactor with superficial air velocity of $3 \mathrm{~mm} / \mathrm{s}$.

In the present research, granular sludge was cultivated in the SBR of the typical shape with a $h / d$ of 2.1 that resulted in the superficial air velocity of only $6 \mathrm{~mm} / \mathrm{s}$. McSwain Sturm and Irvine (2008) have shown that dissolved oxygen (DO) and substrate removal kinetics are more significant to granule formation than the shear force. At a high DO, biodegradable substrates disappear quickly which results in a long famine period in the SBR. The length of the SBR cycle in our research was $12 \mathrm{~h}$, with feast period of $\approx \approx 4 \mathrm{~h}$ (see Fig. 3b). During the remaining $8 \mathrm{~h}$, a famine period lasted with the high DO concentration that promoted aerobic granulation.

Fig. 1 Images of aerobic granules in the 140th cycle of the experiment (microscopic image)
OLR is one of the factors influencing the formation of aerobic granules. Tay et al. (2004) reported that it is difficult to form granules at OLR $<2 \mathrm{~kg} \mathrm{~m}^{-3}$ day $^{-1}$ COD. Wang et al. (2009), however, managed to cultivate granules at an OLR of $1.05-1.68 \mathrm{~kg} \mathrm{~m}^{-3}$ day $^{-1}$. COD in the present research wastewater composition entailed an OLR of only $0.45 \mathrm{~kg} \mathrm{~m}^{-3}$ day $^{-1}$, and experimental results proved that the aerobic granulation was still possible even at such a low OLR.

During the experiment, the efficiency of the removal of COD was $80 \pm 11 \%$. At the beginning, the reactor was fed with synthetic wastewater containing ammonia at the level of about $150 \mathrm{mg} / \mathrm{L}(\mathrm{COD} / \mathrm{N}=2)$ resulting in the nitrogen load of $0.15 \pm 0.01 \mathrm{mg} \mathrm{NH}_{4}{ }^{+}-\mathrm{N} \mathrm{g} \mathrm{TSS}{ }^{-1}$ day $^{-1}$. From about the 20th cycle, the ammonia concentration in the effluent decreased to $<5 \mathrm{mg} / \mathrm{L}$; simultaneously, oxidized forms of nitrogen appeared in the effluent reaching in cycle 95 about 60 and $90 \mathrm{mg} / \mathrm{L}$ of $\mathrm{NO}_{3}-\mathrm{N}$ and $\mathrm{NO}_{2}-\mathrm{N}$, respectively (Fig. 2).

In cycle 95, the ammonia concentration in the influent had doubled $(\mathrm{COD} / \mathrm{N}=1)$, and the nitrogen load increased to $0.3 \pm 0.002 \mathrm{mg} \mathrm{NH}_{4}{ }^{+}-\mathrm{N} \mathrm{g} \mathrm{TSS}{ }^{-1}$ day $^{-1}$. After increasing the ammonia load, the nitrate-nitrogen concentration dropped to $\approx 50 \mathrm{mg} / \mathrm{L}$, suggesting that nitrite oxidation diminished. Since cycle 140 , the $\mathrm{NO}_{2}{ }^{-}-\mathrm{N}$ concentration increased to about $190 \mathrm{mg} / \mathrm{L}$ in parallel to the decrease in the ammonia level in the effluent to $<1 \mathrm{mg} / \mathrm{L}$ corresponding to ammonia removal efficiency of over $99 \%$ (Fig. 2). In the final stage of the experiment, the prevailing oxidized form of nitrogen $\left(83 \%\right.$ of $\left.\mathrm{NO}_{\mathrm{x}}\right)$ was nitrite.

Ammonia removal in the reactor followed 0 -order kinetics, and the specific ammonia nitrogen removal rate of granules was very high, reaching $24.6 \mathrm{mg} \mathrm{g} \mathrm{VSS}{ }^{-1} \mathrm{~h}^{-1}$ (Fig. 3a). Nitrification rate, calculated as the increase in nitrites and nitrates $\left(\mathrm{NO}_{\mathrm{x}}\right)$, was expressed by 0 -order kinetics and reached $14.3 \mathrm{mg} \mathrm{NO} \mathrm{g} \mathrm{VSS}^{-1} \mathrm{~h}^{-1}$ (Fig. 3c). The removal rate of ammonia nitrogen by aerobic granules obtained in the present research shows that this kind of biomass possesses very good ammonia oxidation capacity.

Nitrite is accumulated under certain conditions which promote ammonia oxidation rate to a point when it exceeds
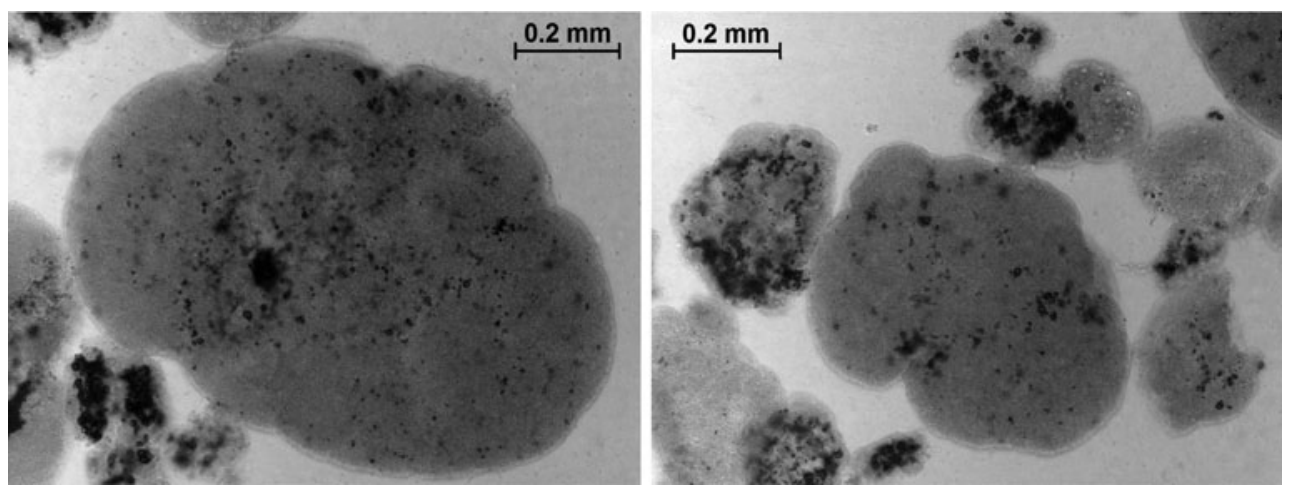
Fig. 2 Nitrogen compound concentration (milligrams per liter) in the influent (inf) and in the effluent (eff) in the course of the experiment ( $n$ cycle number); aerobic granule samples were collected in the cycles marked with arrows

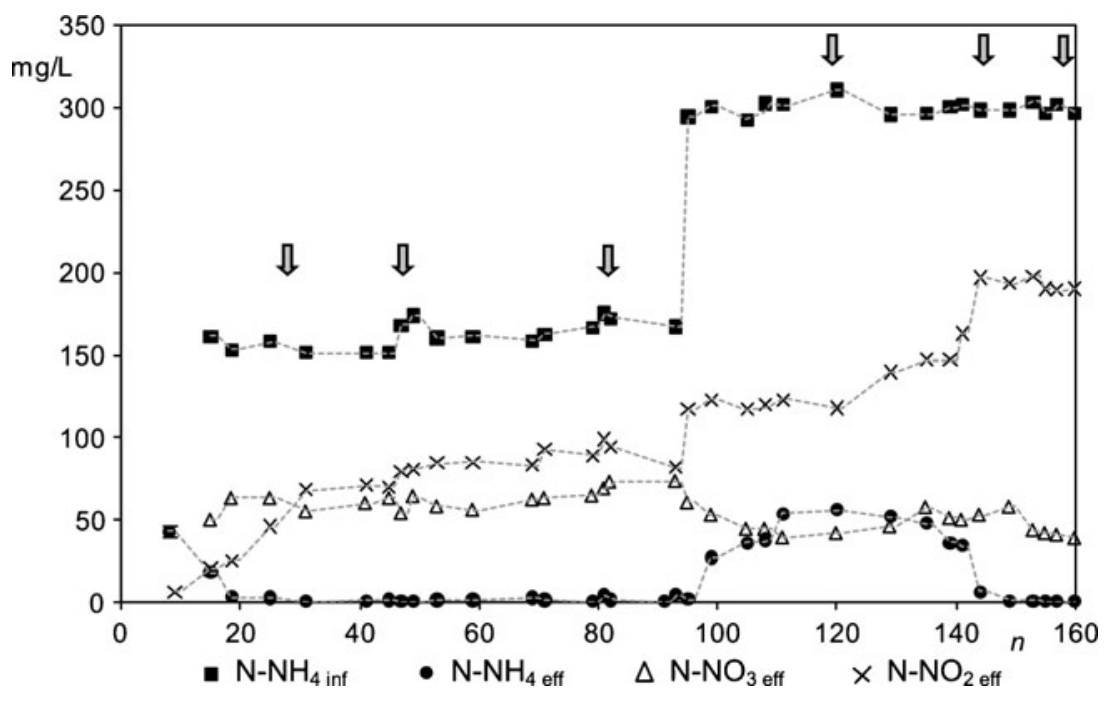

the rate of nitrite oxidation. This is known to result from a number of factors including free ammonia and DO concentration, temperature, or $\mathrm{pH}$ (Schmidt et al. 2003). Since temperature and $\mathrm{pH}$ were controlled in the reactor during the whole experiment, these factors can be excluded. Published data indicate that low oxygen levels result in higher growth yields of AOB while the growth yields of nitrite-oxidizing bacteria (NOB) are unchanged (Tokutomi 2004). In the SBR cycle, DO concentration did not drop below $0.45 \mathrm{mg} / \mathrm{L}$ independently on ammonia load; in fact, for most of the time, it was at the level of $3 \mathrm{mg} / \mathrm{L}$ (Fig. 3d). This suggests that oxygen concentration was not the main factor limiting phase II of nitrification. The fact that nitrite concentration significantly increased in the total amount of $\mathrm{NO}_{\mathrm{x}}$ in the effluent after increasing ammonia load suggests that an inhibition by free ammonia (FA) was the main reason for the changes in the ammonia and nitrite oxidation rates in granular sludge. The calculation of FA concentration performed as described by Ford et al. (1980) indicates that at the higher ammonia load at the beginning of aeration phase, FA equaled $9.6 \mathrm{mg} \mathrm{NH}{ }_{4}^{+}-\mathrm{N} / \mathrm{L}$. According to the published data, the FA inhibition threshold is $10-150 \mathrm{mg}$ $\mathrm{NH}_{4}{ }^{+}-\mathrm{N} / \mathrm{L}$ and $0.1-4.0 \mathrm{mg} \mathrm{NH}_{4}{ }^{+}-\mathrm{N} / \mathrm{L}$ for Nitrosomonas in phase I and Nitrobacter in phase II of nitrification, respectively (Anthonisen et al. 1976; Bae et al. 2001). FA concentration observed in the experiment is higher than the inhibition threshold for Nitrobacter and lower than the FA inhibition threshold for Nitrosomonas that reasonably explains the nitrite accumulation in the effluent.

The low OLR and the long cycle time applied in the experiment negatively influenced the granular sludge production, expressed by biomass yield coefficient $\left(Y_{\text {obs }}\right)$,
Fig. 3 Ammonia (a), average organics (b), oxidized nitrogen form (c), and dissolved oxygen (d) concentrations (all in milligrams per liter) in the reactor in the 162th and 168th cycle; determination coefficient $\left(R^{2}\right)$, constant rate $(k)$, and initial rate $(r)$ were calculated from 0 - or the 1st-order kinetics; squares experimental data, full lines calculated values (a, c 0 -order kinetics, b 1st-order kinetics)
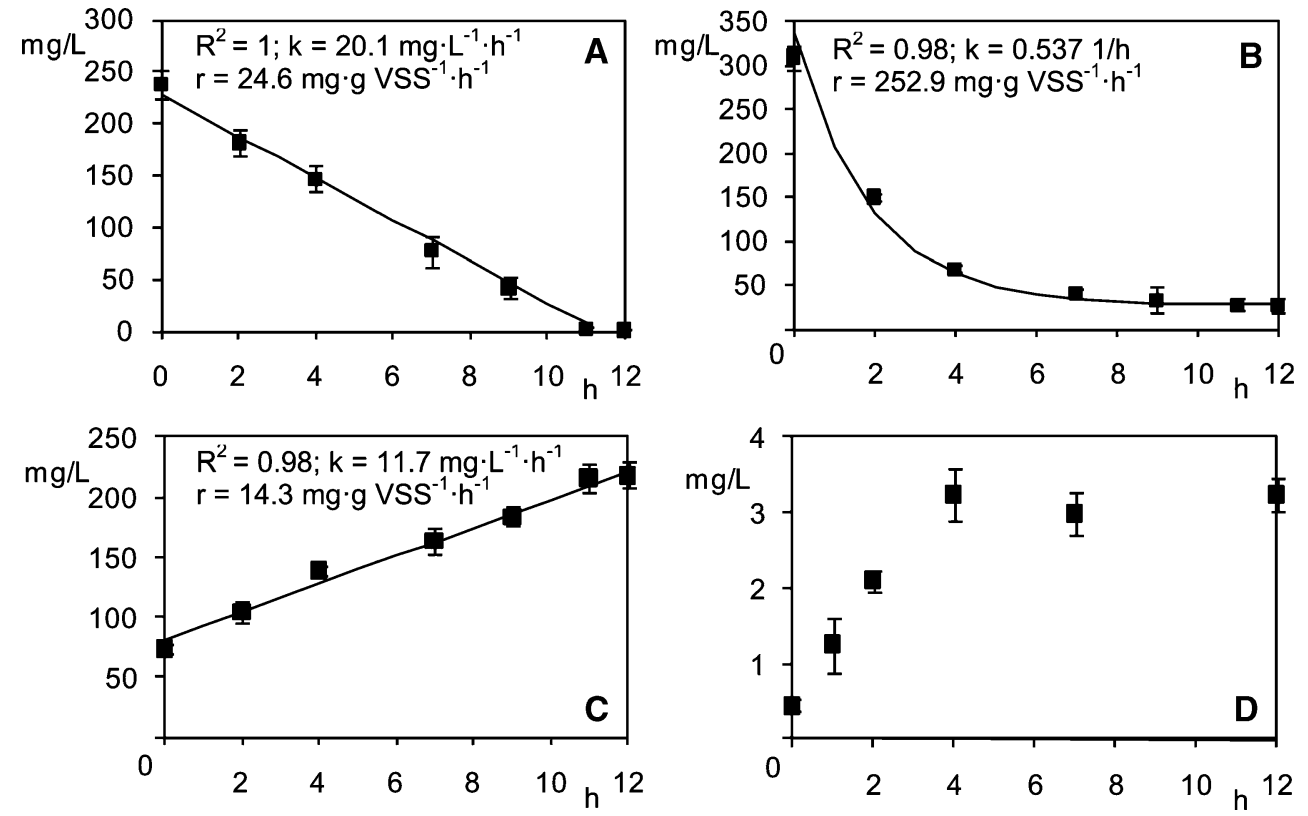
because of low organic carbon availability during the cycle. In the experiment, an average value of $Y_{\text {obs }}$ for OLR of $0.45 \mathrm{~kg} \mathrm{COD} \mathrm{m}^{-3}$ day $^{-1}$ was $0.037 \mathrm{~g} \mathrm{VSS} / \mathrm{g}$ COD and was in accordance with the value expected from the linear relationship between $Y_{\text {obs }}$ and OLR reported by Liu and Tay (2007). A high DO is, on the other hand, related to a lower sludge production resulting from an increased biomass decay rate (Abbassi et al. 1999). Consistently, during most of the SBR cycle, DO concentration was at the level of $3 \mathrm{mg} / \mathrm{L}$ (Fig. 3d), and this fact additionally contributed to the low granule production in the system. Our results point out that the presence of sludge as granules does not guarantee a high biomass concentration in the reactor.

Denitrification in biomass is advantageous not only because it removes nitrogen from wastewater, but also because it improves aerobic granule formation (Wan and Sperandino 2009). At the very low production of aerobic granules and ammonia usage for biomass synthesis, the nitrogen balance shows that $\mathrm{NO}_{\mathrm{x}}$ forms were denitrified despite constant aeration of the reactor. The average denitrification efficiency in the first part of the experiment $(\mathrm{COD} / \mathrm{N}=2)$ was $11.7 \pm 6 \%$, and after increasing the $\mathrm{COD} / \mathrm{N}$ ratio in the influent to 1 , it amounted to $22.7 \pm 9.8 \%$. In the interior of the granules, oxygen diffusion is limited, and anoxic or even anaerobic conditions may appear. According to the study on the relationship between size and mass transfer resistance conducted by Liu et al. (2005), diffusion would be a limiting factor in aerobic granules with a mean size larger than $700 \mu \mathrm{m}$. Therefore, an average granule diameter of $1.9 \pm 1.7 \mathrm{~mm}$ observed in the experiment enabled oxidized nitrogen form reduction in the central parts of granules.

The PCR-DGGE pattern obtained for biomass samples collected during the experiment showed that AOB communities in aerobic granules remained stable throughout the experiment. At an ammonia load of $0.15 \pm 0.01 \mathrm{mg} \mathrm{NH}_{4}{ }^{+}-$ $\mathrm{N} \mathrm{g} \mathrm{TSS}{ }^{-1}$ day $^{-1}(\mathrm{COD} / \mathrm{N}=2)$, the number of amplicons in DGGE pattern equaled 10 (Fig. 4). Most of the labeled amplicons were sequenced; however, only the members of the Nitrosospira genus were identified (Fig. 5), despite seeding granules with a heterologous mixture of AOBAMNITE NS500, containing $N$. europaea as a dominant species. Nevertheless, natural and low ammonia environments usually harbor Nitrosospira ssp. (Mobarry et al. 1996). The fact that Nitrosospira-like bacteria formed the AOB community in granules strongly indicates that the indigenous $\mathrm{AOB}$ species were better adapted to substrate conditions in the reactor and colonized granules instead of the microorganisms from the AMNITE NS500 mixture.

Increasing the ammonia load in wastewater to $0.3 \pm$ $0.002 \mathrm{mg} \mathrm{NH}_{4}{ }^{+}-\mathrm{N} \mathrm{g} \mathrm{TSS}{ }^{-1}$ day $^{-1}(\mathrm{COD} / \mathrm{N}=1)$ influenced the diversity of the AOB community, and three additional amplicons appeared in DGGE pattern: A, L, and G (Fig. 4).

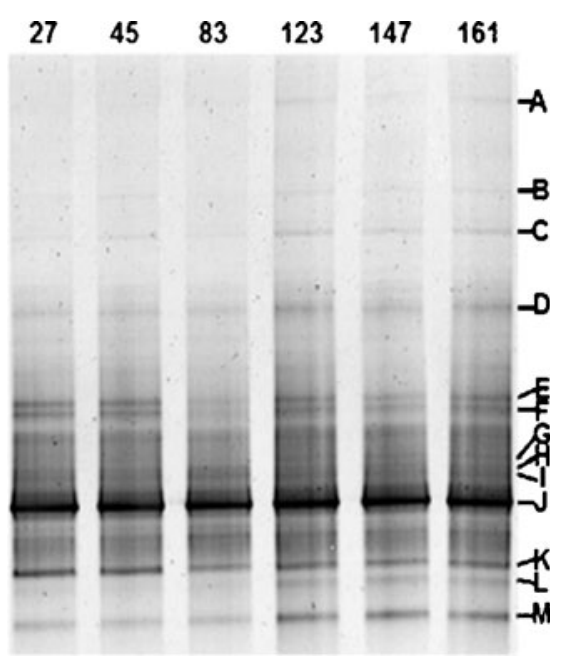

Fig. 4 PCR-DGGE analysis of the amoA gene in activated sludge samples. Lane labels represent the cycle when the sampling was performed; amplicons in the gel are denoted by capital letters; the gel was stained with the SYBRgold fluorescent stain (Molecular Probes, USA)

Sequencing of amplicons $\mathrm{A}$ and $\mathrm{L}$ proved that the first microorganism clustered with Nitrosomonas sp. 107 and Nitrosococcus oceani (band A), and the second one was a bacterium from the Nitrosospira genus (band L). It can be concluded that, at the ammonia load of $0.3 \pm 0.002 \mathrm{mg}$ $\mathrm{NH}_{4}{ }^{+}-\mathrm{N} \mathrm{g} \mathrm{TSS}{ }^{-1}$ day $^{-1}$ in the AOB population, members of the Nitrosospira and Nitrosomonas genera coexisted in the granules that provided a high AOB species diversity, advantageous for the stability of wastewater treatment (Daims et al. 2001). Since the predominant AOB in ammonium-rich systems are members of the genus Nitrosomonas (Mobarry et al. 1996), further increase in ammonia load in our experiment would have probably resulted in a gradual increase in the number of Nitrosomonas-like species in biomass and the prevalence of this genus in the AOB community. Our results confirm that the ammonia load in wastewater is one of the major factors influencing the composition of AOB species in aerobic granules.

DGGE analysis does not allow for the absolute quantification of the phylotypes in analyzed samples due to PCR biases. Even a very weak amplicon in the DGGE pattern may be the dominant species in the investigated biocenosis. That is why the quantification of bacterial groups in mixed microbial communities was performed by a real-time quantitative PCR in the present work. The total number of bacteria estimated on the basis of real-time PCR reaction with specific primers was similar during most of the experiment and oscillated around $7.5 \times 10^{5}$ bacterial cells per reaction tube (Fig. 6). The seeding biomass did not possess nitrification activity. Introduction of wastewater with a $\mathrm{COD} / \mathrm{N}$ of 2 caused that biomass started to gradually 
Fig. 5 The tree of the percentage sequences similarity based on partial sequences of amoA amplicons from granule samples reconstructed by the neighborjoining method using JalView program (Waterhouse et al. 2009). Amplicons excised from DGGE gel are labeled with capital letters; nucleotide sequence database (GenBank) accession numbers are shown in parentheses

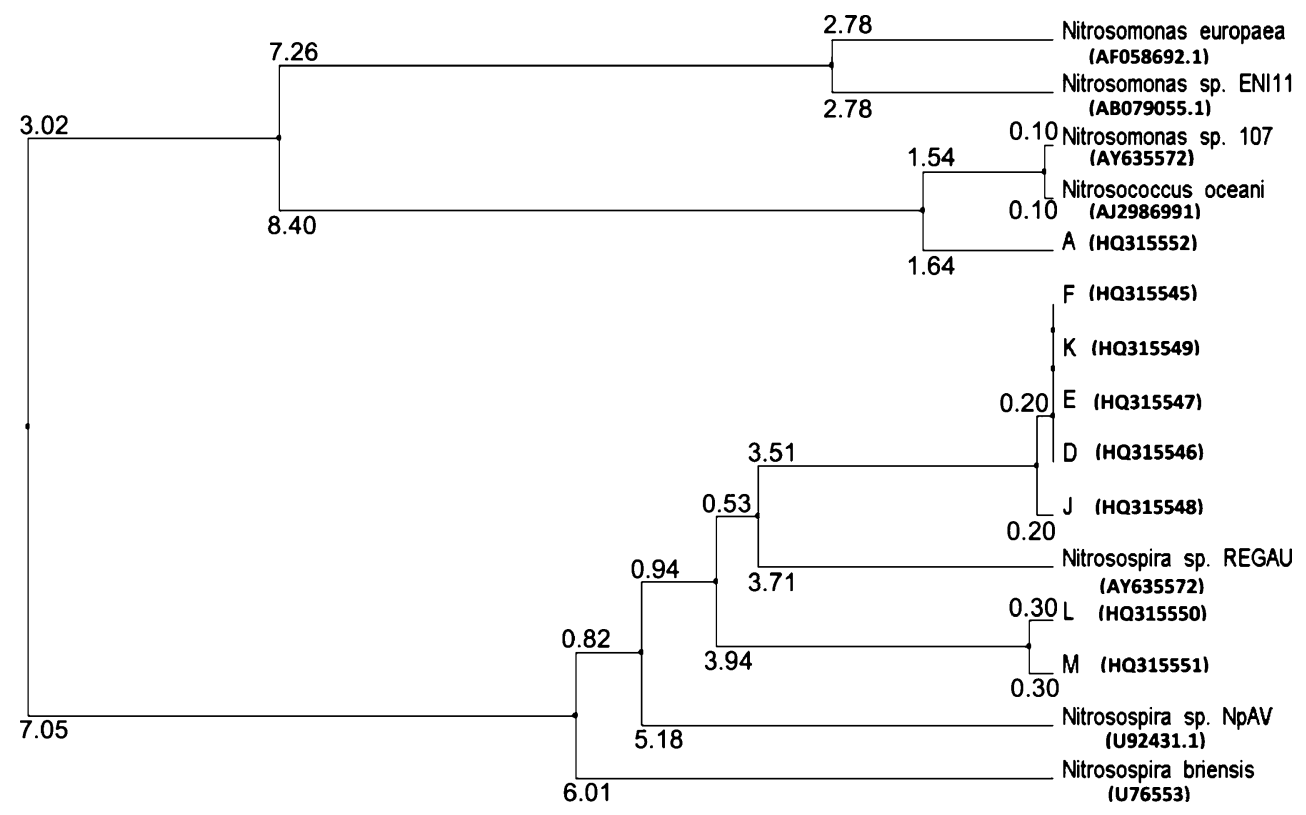

Similar results, obtained, however, on the basis of the FISH technique, were published by Kim and Seo (2006). At the ammonia concentration in the reactor of $300 \mathrm{mg} / \mathrm{L}$ at the beginning of the aeration phase, the representation of AOB in granular sludge was $38.2 \%$. There was a large difference observed between the abundance of Nitrosomonas and Nitrosospira species that occupied $32.8 \pm 0.7 \%$ and $5.4 \pm 0.1 \%$ of the total bacteria, respectively. In our experiment, the appearance of the amplicon denoted as A and corresponding to Nitrosomonas sp. was correlated with the rapid increase in the AOB percentage in biomass, suggesting that the species belonging to this genus dominated in the ammonia-oxidizing community at a higher ammonia load.

The percentage values of $\mathrm{AOB}$ in granular sludge at an ammonia load of $0.15 \pm 0.01 \mathrm{mg} \mathrm{NH}_{4}^{+}-\mathrm{N} \mathrm{g} \mathrm{TSS}^{-1}$ day $^{-1}$ are rather low, suggesting that the figures can to some extent be affected by the limitations of real-time PCR when applied to heterogeneous populations, most often originating from the preferential amplification of particular sequences. The AOB participation in the total amount of bacteria in the final stage of the experiment was, however, very high (40\%) and brings an evidence of the potential of aerobic granular sludge technology for stably maintaining slowgrowing nitrifiers in the technological system.

In the experiment, granular sludge was cultivated in a reactor with typical dimensions, showing that it is feasible to adapt existing facilities to granule-based technology. Application of granular sludge for the treatment of wastewater with a low $\mathrm{COD} / \mathrm{N}$ ratio allowed high $\mathrm{COD}$ and ammonia removal rates to be obtained. The dominating oxidized form of nitrogen was nitrite, and up to $20 \%$ of the oxidized nitrogen was denitrified. In granular biomass, very high percentage (up to $43 \%$ ) of AOB can be obtained.
Fig. 6 The number ( $N$ bacterial cells per reaction tube) of total (gray columns) and ammonia-oxidizing (black columns) bacteria in aerobic granule samples from different cycles ( $n$ cycle number) of the experiment and the percentage of ammonia-oxidizing bacteria (AOB; circles) calculated for each sample; bars standard deviations 
Acknowledgments We thank MSc. K. Selewska for technical assistance. The work was supported by the Polish Ministry of Science and Higher Education.

Open Access This article is distributed under the terms of the Creative Commons Attribution Noncommercial License which permits any noncommercial use, distribution, and reproduction in any medium, provided the original author(s) and source are credited.

\section{References}

Abbassi B, Dullstein S, Raebiger N (1999) Minimization of excess sludge production by increase of oxygen concentration in activated sludge flocs; experimental and theoretical approach. Water Res 34:139-146

Altschul SF, Madden TL, Schaffer AA, Zhang J, Zhang Z, Miller W, Lipman DJ (1997) Gapped BLAST and PSI-BLAST: a new generation of protein database search programs. Nucleic Acids Res 25:3389-3402

Anthonisen AC, Loehr RC, Prakasam TBS, Srinath EG (1976) Inhibition of nitrification by ammonia and nitric acid. J Water Pollut Control Fed 48:835-852

APHA (1992) Standard methods for the examination of water and wastewater, 18th edn. APHA, AWWA and WEF, Washington

Bae W, Baek S, Chung J, Lee Y (2001) Optimal operational factors for nitrite accumulation in batch reactors. Biodegradation 12:359-366

Beun JJ, Hendriks A, van Loosdrecht MCM, Morgenroth E, Wilderer PA, Heijnen JJ (1999) Aerobic granulation in a sequencing batch reactor. Water Res 10:2283-2290

Coelho MAZ, Russo C, Araujo OQF (2000) Optimization of a sequencing batch reactor for biological nitrogen removal. Water Res 34:2809-2817

Cydzik-Kwiatkowska A, Białowiec A, Wojnowska-Baryła I, Smoczyński L (2009a) Characteristics of granulated activated sludge fed with glycerine fraction from biodiesel production. Arch Environ Prot 35:41-52

Cydzik-Kwiatkowska A, Zielińska M, Wojnowska-Baryła I (2009b) Impact of operational parameters on bacterial community in a full-scale municipal wastewater treatment plant. Pol J Microbiol (in press)

Daims H, Purkhold U, Bjerrum L, Arnold E, Wilderer PA, Wagner M (2001) Nitrification in sequencing biofilm batch reactors: lessons from molecular approaches. Water Sci Technol 43:9-18

Ford DL, Churchwell RL, Kachtick JW (1980) Comprehensive analysis of nitrification of chemical processing of wastewaters. J Water Pollut Contr Fed 52:2726-2746

Gilbride KA, Lee D-Y, Baudette LA (2006) Molecular techniques in wastewater: understanding microbial communities, detecting pathogens, and real-time process control. J Microbiol Meth 66:1-20

Head M, Oleszkiewicz JA (2000) Nitrogen removal from wastewater from sludge dewatering. Designing and operation of wastewater treatment plant. (In Polish) Materiały seminarium szkoleniowego, Kraków, pp 61-76

Jin R-C, Zheng P, Mahmood Q, Zhang L (2008) Performance of a nitrifying airlift reactor using granular sludge. Sep Purif Technol 63:670-675

Kim D-J, Seo D (2006) Selective enrichment and granulation of ammonia oxidizers in a sequencing batch airlift reactor. Process Biochem 41:1055-1062
Klimiuk E, Kulikowska D (2006) Organics removal from landfill leachate and activated sludge production in SBR reactors. Waste Manage 26:1140-1147

Lane DJ (1991) 16S/23S rRNA sequencing. In: Stackebrandt E, Goodfellow $M$ (eds) Nucleic acid techniques in bacterial systematics. Wiley, Oxford, pp 205-248

Liu Y, Tay JH (2004) State of the art of biogranulation technology for wastewater teratment. Biotechnol Adv 22:533-563

Liu YQ, Liu Y, Tay J-H (2005) Relationship between size and mass transfer resistance in aerobic granules. Lett Appl Microbiol 40:312-315

Liu YQ, Tay JH (2007) Characteristics and stability of aerobic granules cultivated with different starvation time. Appl Microbiol Biotechnol 75:205-210

McSwain Sturm BS, Irvine RL (2008) Dissolved oxygen as a key parameter to aerobic granule formation. Water Sci Technol 58:781-787

Mobarry BK, Wagner M, Urbain V, Rittmann BE, Stahl DA (1996) Phylogenetic probes for analyzing abundance and spatial organization of nitrifying bacteria. Appl Environ Microbiol 62:2156-2162

Nicolaisen MH, Ramsing NB (2002) Denaturing gradient gel electrophoresis (DGGE) approaches to study the diversity of ammonia-oxidizing bacteria. J Microbiol Meth 50:189-203

Norton JM, Alzerreca JJ, Suwa J, Klotz MG (2002) Diversity of ammonia monooxygenase operon in autotrophic ammoniaoxidizing bacteria. Arch Microbiol 177:139-149

Okano Y, Hristova KR, Leutenegger CM, Jackson LE, Denison RF, Gebreyesus B, Lebauer D, Scow KM (2004) Application of realtime PCR to study effects of ammonium on population size of ammonia-oxidizing bacteria in soil. Appl Environ Microbiol 70:1008-1016

Rotthauwe J-H, Witzel K-P, Liesack W (1997) The ammonia monooxygenase structural gene amoA as a functional marker: molecular fine scale analysis of natural ammonia-oxidizing populations. Appl Environ Microbiol 63:4704-4712

Schmidt I, Sliekers O, Schmidt M, Bock E, Fuerst J, Kuenen JG, Jetten MSM, Strous M (2003) New concepts of microbial treatment processes for the nitrogen removal in wastewater. FEMS Microbiol Rev 27:481-492

Suzuki MT, Taylor LT, DeLong EF (2000) Quantitative analysis of small-subunit in rRNA genes in mixed microbial populations via 5'-nuclease assays. Appl Environ Microbiol 66:4605-4614

Tay JH, Liu QS, Liu Y (2001) The effects of shear force on the formation, structure and metabolism of aerobic granules. Appl Microbiol Biotechnol 57:227-233

Tay JH, Pan S, He Y, Tay STL (2004) Effect of organic loading rate on aerobic granulation. I: Reactor performance. J Environ Eng 130:1094-1101

Toh SK, Tay JH, Moy BYP, Ivanov V, Tay STL (2003) Size-effect on the physical characteristics of the aerobic granule in a SBR. Appl Microbiol Biotechnol 60:687-695

Tokutomi T (2004) Operation of a nitrite-type airlift reactor at low DO concentration. Water Sci Technol 49:81-88

Wan J, Sperandino M (2009) Possible role of denitrification on aerobic granular sludge formation in sequencing batch reactors. Chemosphere 75:220-227

Wang S-G, Gai L-H, Zhao L-J, Fan M-H, Gong W-X, Gao B-Y, Ma Y (2009) Aerobic granules for low-strength wastewater treatment: formation, structure, and microbial community. J Chem Technol Biotechnol 84:1015-1020

Waterhouse AM, Procter JB, Martin DMA, Clamp M, Barton GJ (2009) JalView Version 2 - a multiple sequence alignment editor and analysis workbench. Bioinformatics 25:1189-1191 